\title{
A Comunidade Faz a Revista
}

A comunidade técnico-científica brasileira tem desfrutado nos últimos sete anos dos benefícios de uma revista nacional especializada na área de polímeros. Devemos reconhecer que tem sido essencial a existência de um veículo comum de divulgação dos conhecimentos, realizações e de expressão dos pensamentos e da visão de especialistas da área.

Certamente, ainda existe o questionamento de alguns sobre os novos rumos que devem ser tomados, ou o impacto de publicações em revistas nacionais frente a publicações em revistas internacionais. Mas a força e o reconhecimento da revista Polímeros: Ciência e Tecnologia se deve, em grande parte, pela abrangência nacional que possui. Nenhuma publicação técnico-científica consegue obter o nível de divulgação na comunidade acadêmica e industrial no Brasil, na área de polímeros, que nós conseguimos. Isto acontece justamente pelo fato desta revista ter sido criada com este foco e objetivo, ser dirigida pela própria comunidade e estar sempre aberta a novas idéias e opiniões na busca da melhoria contínua. Inúmeras dificuldades têm surgido a cada ano e sido superadas graças à participação ativa de todos os seus associados, que zelam pela revista como forma de expressão não só do seu trabalho individual, mas principalmente de uma comunidade técnico-científica competente no nosso país.

Um último questionamento que estamos recebendo é sobre o maior impacto de artigos científicos em revistas internacionais. Uma publicação em inglês tem seu devido valor, mas certamente não é a primeira forma de expressão de uma comunidade, pois para isso já existem dezenas de outras revistas internacionais que têm publicado artigos de trabalhos realizados no Brasil. O assunto está aberto para discussões e certamente gostaríamos de receber sua opinião, mas acreditamos que seria um erro tentarmos competir com revistas internacionais e deixar de fazer o papel que uma revista nacional deve fazer, a menos que decidamos, como em outros países como a Índia, que a forma de expressão da nossa comunidade será a língua inglesa. Mesmo assim perderíamos o objetivo principal da nossa revista que é a integração CiênciaTecnologia, Indústria-Universidade e de todos os seus respectivos representantes (técnicos, alunos, empresários, professores, etc). Saber mudar o que tem que ser mudado é uma tarefa importante, mas para isso devemos reconhecer a quem devemos servir, afinal muitas vezes "não podemos servir a dois senhores, pois se agradarmos a um desprezaremos o outro". A revista é feita para você e você faz a revista. 